\title{
ИМАГОЛОГИЯ
}

УДК 82.091

DOI: $10.17223 / 24099554 / 14 / 7$

\section{B.B. Opexов}

\section{ПРЕДЫСТОРИЯ ОТЕЧЕСТВЕННОЙ ИМАГОЛОГИИ: ТРАДИЦИЯ КАК ЦЕЛЕУКАЗАНИЕ}

Анализ российских исследований XIX в. позволяет говорить о формировании отечественной имагологической традиции, в основе которой принцип историчности и первостепенное внимание $\kappa$ образу России в зарубежной литературе. Это дает возможность предложить в качестве актуального объекта современных исследований феномен «ответной рецепции», т.е. прочесс осмысления русскими литераторами европейского образа России (создание «метаобраза»).

Ключевые слова: имагология, ответная рецепџия, метаобраз, имагологический диалог, россика.

Вошло в обычай говорить об имагологии как о «молодом» научном направлении, которое именно в силу своей «юности» находится на стадии активного формирования методологии и понятийного аппарата. Как правило, констатируется, что возникновение имагологии связано с именем французского литературоведа М.-Ф. Гийара, который в 1951 г. заявил о том, что изучение бытующих в литературе мифов о других народах должно открыть новые горизонты перед компаративистикой [1]. Однако некоторые ученые отыскивают истоки имагологии в гораздо более давних эпохах. Голландский профессор Ж. Леерссен полагает, что ранним проявлением имагологии следует считать последовательные попытки европейского Просвещения систематизировать национальные нравы и характеры [2]. Столь значительное разночтение в датировке довольно обширной исследовательской сферы заставляет говорить о необходимости более пристального внимания к ее истории. Причем речь должна идти не столько о фиксации рубежных событий (зародилась - получила но- 
вый импульс к развитию - обновила методологическую базу - продолжает динамично развиваться), сколько о постижении логики, задающей направление и динамику имагологическим исследованиям.

Философия науки руководствуется постулатом, в соответствии с которым «без анализа истории науки невозможно понять тенденции ее будущего развития» [3. С. 155]. Для отечественной имагологии это положение становится все более актуальным, поскольку в последнее время некоторые ее подходы начинают вызывать настороженность или даже разочарование исследователей. Так, скажем, А.Р. Ощепков акцентирует внимание на том, что «Аахенская программа по имагологии» диктует отказ от представлений о нациях как о реальных сущностях [4. С. 252]. В.П. Трыков замечает, что современная западная имагология, опираясь на метод постструктуралистского дискурс-анализа, воспринимает национальные образы как самодовлеющие образования, «живущие» в отрыве от отраженной текстом действительности: «Текст перекликается с текстом, образ с образом, но они никак не соотносятся с социокультурной реальностью $<\ldots>$. Пространство текстов отрывается от пространства истории, социума» [5. С. 123]. На тот же недостаток обращает внимание и Т.В. Якушкина, утверждая, что имагология в ее современной западной традиции превращается в идеологический инструмент и «не замечает» эволюции образа «чужого» [6. С. 164]. На фоне этого особое значение приобретает стремление более пристально всмотреться в отечественный опыт имагологии [7-10], напомнить о вкладе в это направление классиков отечественного литературоведения А.Н. Веселовского, М.П. Алексеева, Б.Г. Реизова, Ю.М. Лотмана и др. [5. С. $126 ; 6$. С. $163 ; 11$. С. $36 ; 12$. С. 54-55]. Но еще более симптоматично, что отечественные ученые нередко выходят за рамки западной методологии, нащупывая новые исследовательские векторы и принципы.

Собственно, уже в размышлениях В.А. Хорева, выявляющего стереотипы национального взаимовосприятия в историческом контексте и ставящего проблему «истинных и ложных представлений о жизни других народов» [13. С. 22], заметен отход от западной методологии, которая видит в образах другого продукт «культурных систем» [14. С. 158], не подлежащий поверке фактами действительности. Совершенно независимой от западной имагологической «про- 
граммы» выглядит задача, которую ставил перед собой А.С. Янушкевич, стремясь осмыслить историю «русского имагологического текста», его «национальное содержание» и роль в формировании национального «образа мира» [15. С. 14]. Продолжением отечественной научной традиции является и заявляющая о себе в разных уголках страны инициатива исследовать «имагологическое наполнение» региональных «текстов» [16-19]. Порой исследователи целенаправленно уходят от самого термина «имагология». В.П. Трыков предлагает называть исследование образа другого с позиций исторической поэтики - «имагопоэтикой» [5. С. 127], С.К. Милославская вводит в оборот российский эквивалент термину «имагология» «образоведение» [20. С. 10].

Все это напоминает описанную Т. Куном «революционную ситуацию», когда в «узком подразделении научного сообщества» созревает сознание, что «существующая парадигма перестала адекватно функционировать при исследовании того аспекта природы, к которому сама эта парадигма раньше проложила путь» [21. С. 128]. Вряд ли нынешнее положение дел следует отождествлять с «научной революцией» в полном смысле слова, но уместно констатировать, что в российской имагологии наметился перелом, который характеризуется поиском новых - cвоих - целей и подходов в научном освоении имагологического материала. В некоторых работах еще можно встретить как бы случайно брошенные слова, что «западная наука в области имагологии предстает в качестве наставника» [22. С. 115], но общая картина свидетельствует, что отечественная имагология все увереннее отыскивает собственный путь.

По утверждению В.И. Вернадского, ценность истории науки заключается, среди прочего, в том, что позволяет в прошлом научной дисциплины увидеть то, «о чем и не догадывались прежние исследователи», поскольку «каждое поколение научных исследователей ищет и находит в истории науки отражение научных течений своего времени» [23. С. 203]. Отталкиваясь от этой мысли, полагаем целесообразным проследить первые шаги в освоении имагологического материала, предпринятые отечественной мыслью.

Уже упомянутая нами попытка Ж. Леерссена отыскать корни имагологии в эпохе европейского Просвещения (этот период исследователь называет «археологией» имагологии), думается, следует 
считать некоторой натяжкой. Интерес деятелей Просвещения Д. Юма, Вольтера, И.Г. Гердера и др. - был направлен на изучение и фиксацию самих национальных нравов и характеров, а не на осмысление национальных образов. Эти авторы могут считаться основоположниками антропологии и этнографии, но не имагологии. Они лишь созидали предмет для будущих имагологических исследований. В том же ключе следует расценивать «Письма русского путешественника» Н.М. Карамзина и запечатленные в них национальные образы. Целью писателя было создать образы, а не исследовать их. В качестве исключения можно рассматривать лишь те немногие эпизоды, где Карамзин обращает внимание на отношение иностранцев к герою «Писем...» как представителю России, т.е. пытается осмыслить европейские национальные стереотипы.

Возникновение в русском обществе небывалого по интенсивности и масштабу интереса к национальным образам было вызвано Отечественной войной 1812 г. и победой над Наполеоном. Причем интерес этот был направлен, прежде всего, на французские представления о России и русских. Тому способствовало стечение двух важных факторов. Во-первых, после вступления русской армии в Париж в 1814 г. огромное количество русских получило возможность в условиях мирной жизни познакомиться с французскими мнениями, о которых прежде узнавали в основном со слов французских эмигрантов и соотечественников, бывавших за границей. Вовторых, Отечественная война чрезвычайно актуализировала в российском обществе «идеал национальной консолидации» [24. С. 473], катализировала «процесс нациостроительства $<\ldots>$, поставив перед общественным сознанием целый ряд проблем» [25. С. 455]. Одной из этих проблем было очевидное несоответствие между французскими предубеждениями в отношении России и настоящим положением вещей. И торжествовавшее в тот период российское национальное единство нацеливало все общественные слои и институты - не по приказу, а, что называется, по велению души - на коррекцию европейских представлений о России и русских.

На первом этапе происходило лишь знакомство с мнениями французов. Записки большинства участников тех событий содержат колоритные рассказы на этот счет. В качестве типичного эпизода приведем фрагмент из парижского письма К.Н. Батюшкова Н.И. Гнедичу: 
«В числе народа были и порядочные люди, и прекрасные женщины, которые взапуски делали мне странные вопросы: отчего у меня белокурые волосы, отчего они длинны? < .. > "Посмотри, у него кольцо на руке. Видно, и в России носят кольца. Какая длинная лошадь! Степная, верно степная". < ..> “Какие у него белые волосы!” “От снегу”, ответил старик, пожимая плечами» [26. С. 272].

Этот стихийный интерес к своему отражению в чужом коллективном сознании дал первый толчок к целенаправленному сбору имагологической информации. В январе 1815 г. генерал-майор кн. С.Г. Волконский (будущий декабрист) сообщал из Парижа П.Д. Киселеву (будущему послу в Париже в 1856-1862 гг.): «Я составляю здесь коллекцию из всех сочинений, которые уже созданы и которые создаются против нас и в защиту нас. Невообразимы все те басни, которые рассказывают о нас и, в особенности, о кампании 1812 года» [27. С. 210]. А уже в конце 1815 г. директор Императорской публичной библиотеки А.Н. Оленин настаивал на необходимости создания фонда «иностранных сочинений, касающихся до России, и особенно тех из них, кои относятся к знаменитой войне 1812 , 1813 и 1814 годов» [28. С. 8].

Эта идея получила значительное продолжение, поскольку интерес к европейскому восприятию России передался от поколения участников Наполеоновских войн к поколению ровесников А.С. Пушкина. В начале $1820-$ х гг. лицейский однокашник поэта М.А. Корф начал составлять «полный библиографический каталог всех книг и пр., когда-либо изданных о России <.. >, на всех языках» [29. Т. 16. С. 164-165], позднее пригодившийся Пушкину для изучения эпохи Петра I [29. Т. 10. С. 402-412]. Служебная карьера надолго отвлекла Корфа от этой сферы интересов, пока в 1849 г. он не был назначен на пост директора Императорской публичной библиотеки (ныне - РНБ), где организовал особое отделение «Россика», «предназначенное собирать все опубликованные на иноземных языках книги, связанные с Россией в каком бы то ни было отношении» [30. C. I]. Поиск книг для «Россики» стал стержневым направлением библиотечной работы на годы вперед. В результате полнота коллекции по некоторым темам (скажем, о войне 1812 г.) достигла 90\% [31. С. 54]. В дальнейшем именно эта коллекция давала возможность отечественным и зарубежным ученым (М.П. Алексееву, Б.Л. Модза- 
левскому, Е.В. Тарле, М. Кадо и др.) изучать литературное мнение Запада о России. «Россика» и сегодня сохраняет свое значение для исследований в этом направлении.

Закономерно, что деятельность Корфа по созданию «Россики» началась с юношеского увлечения библиографией зарубежных трудов. Актуальность подобной работы начинала сознаваться наукой. Ключевое значение в этом отношении сыграла деятельность немецкого ученого, поступившего на русскую службу, Ф.П. Аделунга [32], который по инициативе графа Н.П. Румянцева занялся исследованием европейских исторических источников о России. Сын Ф.П. Аделунга, Н.Ф. Аделунг (продолжавший, кстати, его дело), свидетельствовал, что отец обратился, прежде всего, к древней истории Руси, когда «Карамзин уже с успехом приступил к обработке туземных источников», и это подвигло его «обратить тем большее внимание на известия иностранцев о древней Руси, чем меньшее вообще дотоле им оказывали» [33. Ч. І. С. III]. М.В. Нечкина также подчеркивала, что Ф.П. Аделунг «считал свою работу связанной с трудом Карамзина», «полагал, что Карамзин будет основываться на русских источниках, а он, Аделунг, параллельно будет освещать в основном ту же тематику по иностранным источникам» [34. С. 109].

В итоге исследование Ф.П. Аделунга оказалось не похожим ни на историю России, созданную по зарубежным памятникам, ни на собрание этих памятников. Это был энциклопедического охвата труд, который сегодня мы назвали бы биобиблиографическим указателем, - «Критико-литературное обозрение путешественников по России до 1700 года и их сочинений» [33]. Автор готовил для этого обозрения 265 самостоятельных статей (завершены не все) и явно ориентировался на интересы исторической науки. Однако его работа стала важным пособием для исследования европейских представлений о России разных эпох. Так что сегодня отечественными исследователями исторической имагологии Ф.П. Аделунг воспринимается как один из основоположников этой области знаний [35. С. 756].

Собирание и описание зарубежных источников открывало путь к их публикации на русском языке и критическому осмыслению. М.А. Корф в 1822 г. напечатал работу, представлявшую Россию начала XVII в. глазами датского посольства [36]. Некоторые исследовательские сюжеты Ф.П. Аделунга превратились в самостоятель- 
ные издания. В 1818 г. он опубликовал на немецком языке монографию о путешествии в Россию Герберштейна, а в 1827 г. (опять же на немецком языке) - биографический труд о бароне Мейерберге. В том же 1827 г. это издание появилось в переводе на русский язык [7]. Но важно, что подобного рода деятельность быстро вышла за пределы узкого круга «посвященных» и оказалась востребована широкой публикой. Публикация иностранных текстов о России стала одним из важнейших направлений журнальной жизни XIX в.

Переводы иностранных текстов о России регулярно публиковали все ведущие издания той поры: «Сын Отечества», «Отечественные записки», «Северный архив», «Современник», «Библиотека для чтения», «Русский вестник», «Журнал Министерства народного просвещения» [38. С. 43-45]. Зачастую переведенные произведения побуждали редактора или переводчика к критическому анализу. Но поскольку методология подобного анализа лишь вырабатывалась, то перед публикаторами открывалось широкое поле экспериментов, иные из которых выглядели довольно курьезно. Приведем такой эпизод. В 1841 г. Н.И. Греч возобновил издание «Русского вестника», открыв в журнале рубрику «Известия иностранцев о России». Среди прочего здесь печатались записки англичанина Самуила Коллинса, жившего в России в эпоху царя Алексея Михайловича. Отечественный переводчик сопроводил текст примечаниями, о характере которых можно судить по следующим выпискам. Англичанин, например, заявляет, что в России, «если кто из протестантов или католиков отрекается от своей веры, то он должен также отречься от своего первого крещения, проклясть своего отца и свою мать и плевать на них три раза через свое плечо». Переводчик запальчиво возражает: «Бесстыдная ложь!» [39. С. 164] Далее английский автор уверяет, что в России покойнику «в руку дают удостоверение местного митрополита для донесения Св. Николаю Чудотворцу о доброй жизни и хороших нравах покойника». Переводчик снова не выдерживает: «Можно ли налгать таких глупых вздоров и не стыдиться печатать их?» [39. С. 171] В конце концов, переводчик резюмирует, что записки Коллинса - «лжи и клеветы на Россию и на русских» [39. C. 595].

Подобная эмоциональность как единственный способ аргументации уже в то время смотрелась наивно, а потому, как правило, для 
объяснения «иностранных известий» использовались логические приемы. Примером может служить работа А.С. Пушкина над подготовкой к печати в «Современнике» «Мемуаров...» французского офицера Моро-де-Бразе, принимавшего участие в Прутском походе Петра I. Пушкин придавал большое значение иностранным известиям как историческому источнику [40], однако для поэта было очевидным, что безоговорочное доверие к иностранным текстам неоправданно. Пушкин указывает, какие пассажи в повествовании Моро-де-Бразе грешат «вольными суждениями» [29. Т. 10. С. 253], т.е. субъективностью, искажающей историческую истину. Более того, Пушкин стремится объяснить истоки этой субъективности и называет ряд факторов: 1) «Моро не любит русских и не доволен Петром» [29. Т. 10. С. 253]; 2) француз испытывает «простодушную досаду» на Петра I за приверженность царя к мнениям русских офицеров; 3) французу свойственна «забавная ветреность»; 4) Моро - «иностранец, приверженный к своей партии» [29. Т. 10. С. 259]. Словом, Пушкин не просто оспаривает частные свидетельства, а стремится выявить закономерности, формирующие представления иностранного автора о России, приступает к решению той самой задачи, которая сегодня оказывается в ведении имагологии, а в то время привлекала внимание и широкой публики, и, соответственно - публицистики, но, прежде всего, - историков.

Важным явлением исторической науки той поры стало выпущенное Н.Г. Устряловым пятитомное собрание переведенных на русский язык иностранных источников «Сказания современников о Дмитрии Самозванце» (1831-1834). Тексты снабжены примечаниями составителя, где объясняются «известия темные или неверные» [41. Ч. IV. C. III]. Порою необъективным сведениям иностранных авторов историк противопоставляет архивные документы, чтобы читатель мог убедиться в «неосновательности» некоторых суждений [41. Ч. II. С. Х]. И обратим внимание: Устрялов стремится найти объяснение недостоверным свидетельствам иностранцев. Так, предвзятость М. Бера он объясняет «тайной злобой» автора или его неспособностью постичь «дух времени» [41. Ч. І. С. XV]. В сочинении Паерле усматривает «злобу на москвитян», рожденную неудачами иностранцев, пытавшихся вмешаться в дела Московского государства [41. Ч. II. С. IX]. Историк стремится выделить условия, оказавшие 
воздействие на образ России и русских в зарубежных текстах. Это отражает логику, руководившую и другими историками в работе с иностранными «сказаниями»: в качестве первоочередной задачи рассматривалось «критическое издание текста сказаний и определение степени их достоверности» [42. С. III], а это актуализировало очередную задачу - выяснение факторов, формирующих зарубежные представления о стране.

Этот алгоритм работы с иностранными источниками характерен и для современной исторической науки. Но обратимся к одному исследованию XIX столетия, которое задумывалось автором и воспринималось читателями как историческое, однако не укладывалось тогда (и не укладывается сегодня) в классическую парадигму исторической науки. Речь идет о книге В.О. Ключевского «Сказания иностранцев о Московском государстве» (1866). Несмотря на созвучие с заглавием устряловского собрания текстов, Ключевский использует совершенно иной подход к освоению материала. Он опирается на три десятка уже опубликованных источников и пересказывает (не цитирует, а именно пересказывает) их фрагменты таким образом и в такой последовательности, чтобы они представляли собой единое повествование о Московском государстве. Историк «входит в роль» европейского читателя, представляющего Московию лишь по свидетельствам путешественников, и, как мозаику, «собирает» из эпизодов разных текстов образ Московского государства, бытовавший в европейском сознании. Даже географическая составляющая сигнализирует о мифологичности этого образа: «На севере <...> Московия простирается до Ледовитого океана $<\ldots$.. >; на этих пространствах живут бесчисленные племена в безграничных лесах, которые, не прерываясь, тянутся на северо-восток до Гиперборейской Скифии и никому не известного Скифского океана <..>» [43. С. 16-17]. Несмотря на очевидную ошибочность многих иностранных «показаний», Ключевский почти не допускает критических реплик в отношении зарубежных источников, поскольку его цель - не проверить их истинность, а реконструировать рождаемый ими целостный образ страны. Труд Ключевского сконцентрировал внимание уже не на отдельных иностранных свидетельствах по поводу отдельных фактов, а на коллективных представлениях европейцев о России; он наглядно продемонстрировал, что эти представления сводились не к про- 
стому набору разрозненных сведений, а представляли собой целостную структуру, завершенный образ. И реконструкция, реализованная Ключевским, открывала путь к исследованию этого образа: его природы, соответствия действительности, устойчивости, литературного функционирования и т.д. Следствием такого шага стало, скажем, выяснение одной из принципиальных особенностей чужого взгляда на страну: первоочередное внимание к обыденным предметам. Сам Ключевский формулировал эту особенность так: «Повседневные явления, мимо которых без внимания проходили современники, <..> прежде всего останавливали на себе внимание чужого наблюдателя $<\ldots>$; иностранец <...> описать их <...> мог лучше и полнее, нежели люди, которые пригляделись к подобным явлениям» [43. С. 7]. В дальнейшем суть этого наблюдения многократно подтверждалась исследованиями других отечественных авторов, например, Л.П. Рущинского [44. С. 3] или М.О. Кояловича [45. С. 84], и наконец, была определена Ю.М. Лотманом как нацеленность иностранных авторов на описание «норм жизни» чужой страны в качестве достопримечательности, а «эксцессов»- в качестве «норм» [46. С. 125].

Итак, в XIX в. определились взаимодополняющие направления в освоении россики: 1) обнаружение и описание источников; 2) их перевод и осмысление в своей национально-культурной среде; 3) проверка истинности содержащихся в зарубежных источниках сведений; 4) выявление факторов, формирующих представления иностранных авторов о России; 5) реконструкция обобщенного образа страны, позволяющая анализировать особенности коллективных (т.е. имеющих стереотипную или даже мифологическую природу) представлений.

Очевидно, что эти направления так или иначе и ныне способствуют исследованию национальных образов. Однако можем ли мы считать перечисленные нами факты началом истории отечественной имагологии как самостоятельной области знаний?

Говорить о возникновении какой-либо научной дисциплины можно с того момента, как она начинает сама себя осознавать [47. C. 7,38$]$, т.е. определять свои цели и задачи. Исходя из перечисленных фактов, можно заключить, что в первой половине XIX в. русская наука и общественная мысль как раз начинали осознавать цель изучения образа России в иностранных текстах. Закономерно, что 
историками эта цель виделась в контексте свойственных им научных интересов: использовать иностранные тексты, чтобы увидеть отечественную историю сквозь чужую оптику, «улавливающую» специфический спектр фактов и явлений. А это определяло конкретные задачи: поиск и перевод источников, проверка истинности иностранных «показаний» и т.д. Что касается общественной мысли, то здесь необходимость изучать образ России в «европейском зеркале» подсказывалась актуальной ситуацией русско-европейских отношений, то и дело обретавших напряженный характер. Так, М.А. Корф при создании отделения «Россика» утверждал, что эта коллекция «удержит многих недоброжелателей и хулителей Росси от легкомысленных нареканий и толков - страхом обличения, теперь часто невозможного по недостатку материалов» [48. С. 43]. А.С. Пушкин в 1831 г., ходатайствуя о разрешении «взяться за редакцию политического и литературного журнала», набрасывал в черновике и такое, например, предложение: «Ныне, когда <..> озлобленная Европа нападает покамест на Россию не оружием, но ежедневной, бешеной клеветою <..>», «пускай позволят нам, русским писателям, отражать нападения иностранных газет» [29. Т. 14. С. 283]. Российским обществом исследование иностранных текстов о России воспринималось как прикладная общественно-политическая задача, которая открывает путь к решению следующей задачи - «редактированию» европейских представлений о России с целью защиты российского национального имиджа.

Это разное видение целей определило разную дальнейшую судьбу «имагологических интересов». Наука сосредоточилась на выяснении общих закономерностей, обусловливающих специфику национального образа в чужом тексте. А русская литература и публицистика сконцентрировали усилия на коррекции иностранных представлений о России.

Сначала скажем о «научной судьбе». Очевидно, что первые российские наблюдения имагологического характера были призваны служить интересам исторической науки. И в этом отношении они, безусловно, могут восприниматься как истоки «исторической имагологии» [49. С. 126-128], которая сегодня завоевывает все большую популярность и даже рождает собственные ответвления, скажем «потестарную имагологию», изучающую «образы власти» [50. С. 7]. 
Может сложиться впечатление, что генетическая связь первых имагологических наблюдений с исторической наукой делает сомнительной их родство с имагологией $\mathrm{XX}$ в., которая воспринимается как производная литературной компаративистики, имеет современный терминологический аппарат, наконец, ставит перед собой не известные XIX в. цели, скажем, исследование архаической природы национальных стереотипов - «неумирающего способа имагологического культуротворчества» [51]. Однако научная практика говорит о том, что результаты имагологических поисков XIX в. нередко оказываются востребованными современностью. Достаточно вспомнить уже упомянутую преемственность литературоведческих умозаключений Ю.М. Лотмана от наблюдений историка В.О. Ключевского.

Всякая живая сфера научных интересов способна переживать смену парадигмы и обновлять свою междисциплинарную «валентность». Скажем, археология при своем зарождении воспринималась как отрасль искусствоведения [52. С. 9] и ограничивала свои задачи «исканием и изучением изящных произведений античной культуры» [53. С. 1]. Так что первые российские исследователи древностей даже не называли себя археологами [54. С. 54]. И лишь в 1820-е гг. наметился сдвиг, заставивший археологию признать в качестве магистральной цели изучение истории народов, а не истории искусств [55. С. 325]. В ходе развития той или иной области науки может быть многократно переосмыслен предмет познания и, соответственно, модифицированы методики исследований. Яркий пример тому - лингвистика, трактующая ныне понятие «язык» далеко не так, как это было при зарождении филологической науки [56. С. 18]. Смена парадигм, переосмысление предмета и методов исследования не обнуляют прежних научных достижений, а лишь заставляют «преобразовать» и «переистолковать» их в новых научных условиях [56. С. 17].

Преемственность современной российской литературоведческой имагологии от первоначальных имагологических интересов первой половины XIX в. станет более очевидной, если мы вспомним, что имагологические наблюдения М.П. Алексеева, Б.Г. Реизова, Ю.М. Лотмана, А.К. Виноградова основывались на изучении истории литературы и межлитературных контактных связей - литературоведческих сфер, наиболее прочно связанных с собственно исторической наукой. Это, пожалуй, сближает нашу имагологию с трудами некоторых запад- 
ных компоративистов, например М. Кадо [57] и Ш. Корбе [58], чьи исследования «являясь имагологическими по тематике, не являются таковыми по своим методологическим подходам» [59. С. 63]. Скажем точнее: не согласуются с методологическими подходами в имагологии, сложившимися в Европе чуть позднее.

При внимательном рассмотрении можно заметить, что современная отечественная имагология также не вполне вписывается в европейскую традицию. Она уже имеет свои «прецедентные тексты» [7. С. 142], как например, монография Н.П. Михальской «Образ России в английской художественной литературе IX-XIX вв.» [60]. И, что характерно, «путь» этого исследования, реконструирующего целостный образ России по множеству источников и обнаруживающего черты его мифологичности, в большей степени роднит труд Н.П. Михальской с подходом В.О. Ключевского, нежели с западной имагологической методологией.

Кстати скажем, что та же тенденция наблюдается и в украинской имагологии: часто ссылаясь на теоретические работы французских и голландских имагологов, украинские коллеги в качестве «прецедентных текстов» все же указывают (причем не только литературоведы, но и лингвисты [61. С. 73]) труды известного украинского ученого Д.С. Наливайко $[62,63]$, в которых по европейским источникам реконструируется образ Украины, но с подчеркнутой опорой на принцип историзма, что в известной мере делает работы Д.С. Наливайко независимыми от современной европейской методологии.

Очевидно, что в отечественной имагологии складываться собственная научная традиция, обладающая специфическими чертами. И это, кроме историзма, еще и изначальный и первостепенный интерес не столько к образу чужого, сколько к своему образу в чужом тексте, в чужом общественном сознании. Такие особенности имагологических интересов продиктованы особенностями национальной истории, которая с петровской эпохи демонстрировала стремление русской культуры утвердиться среди европейских культур на правах равной, а на пути к этому - разрушить устаревшие представления о дремучей России, демифологизировать негативные стереотипы. Именно разность изначальных импульсов к возникновению имагологических интересов определяет методологический разрыв между отечественной и западной имагологией и обусловливает существо- 
вание двух неодинаковых, опирающихся на разную традицию, но дополняющих друг друга направлений в изучении одного предмета. Для литературоведения подобная ситуация не нова. Вспомним о переплетающихся, но не идентичных судьбах сравнительно-исторического литературоведения и компаративистики, теории читательского восприятия и рецептивной эстетики и т.д.

Российская имагология уже сейчас накопила немалый багаж знаний об отражении России в зеркале чужих национальных культур. И, думается, пройденный в этом направлении путь позволяет нам расширить угол видения имагологической проблематики. В связи с этим вернемся к тому вопросу, что российская общественная мысль первой половины XIX в. воспринимала в качестве актуальной задачи коррекцию зарубежных представлений о России. Литераторы вступали в своего рода заочный (а порою и непосредственный) «спор» с зарубежными авторами, в межлитературный имагологический диалог. В свое время реакцию русской литературы на зарубежную рецепцию России мы предложили называть «ответная рецепция» [38. C. 62]. Не убеждены, что термин вполне удачен, но нет сомнений, что масштаб самого явления был огромен, и среди литераторов той эпохи мы, пожалуй, не сможем назвать ни одного имени, не причастного к созданию общенационального текста ответной рецепции.

Реакция на иностранную рецепцию России приобретала самые разнообразные формы. Она могла иметь вид прямого отклика на негативные мнения, как, скажем, ода «Клеветникам России» и целый ряд подобных стихотворений. Она могла выражаться и в стремлении к личному знакомству с иностранным автором с целью влиять на его восприятие России. Так было в период российского путешествия А. Дюма, когда «шефство» над романистом взяли Н.А. Некрасов и Д.В. Григорович. Часто ответ на зарубежную рецепцию был «опосредован», адресован не напрямую зарубежным авторам, а российской публике, чтобы помочь ей осмыслить зарубежный образ России или предложить ей возможные варианты ответа на иностранные мнения о России. Отечественная литература училась имитировать зарубежные стереотипы. Скажем, в «Рославлеве...» М.Н. Загоскина мы во множестве встретим отзывы о России, вложенные автором в уста французских персонажей. Порой имитация иностранного взгляда служила приемом, позволяющим показать российскую реальность 
сквозь качественно новый объектив, как в «Письмах знатного иностранца» К.М. Станюковича [64], а иногда становилась инструментом литературной мистификации, как в «письмах» А. Омер де Гелль, подделанных П.П. Вяземским. Авторами, вступавшими в русскоевропейский имагологический диалог, руководили разные мотивы: от чувства патриотизма и политических убеждений до карьерных соображений. Русский текст «ответной рецепции» создавался в разных условиях: и при поддержке власти, и вопреки ее желанию, на территории России и за ее пределами, в периоды международного штиля и в моменты кризисов. Ответная рецепция не только являлась движущей силой беспрерывного имагологического диалога, но и стимулировала создание своего образа России (в современной терминологии «автообраза» [65. С. 129]), способного служить оппозицией образу, созданному чужим сознанием. Все это превращает изучение текста ответной рецепции в масштабную и многоаспектную задачу.

Характерно, что в недавнее время европейские ученые тоже начали обращать внимание на феномен видения себя сквозь призму чужсого сознания. В 2016 г. Ж. Леерссен отметил, что имагология, среди прочего, должна рассматривать метаобразы, т.е. «Наши представления о том, что о нас думают Другие, и представления Других о том, что о них думаем Мы» [66. Р. 21]. Специфику «метаобразов» Леерссен описывает весьма бегло, но ясно, что речь идет о том самом феномене ответной рецепции. И можно предположить, что важную роль в исследовании этого феномена сыграет именно отечественная имагология, поскольку ее первые опыты XIX в. сами являлись одним из направлений русской ответной рецепции, ее научным воплощением, реакцией российской науки на европейские представления о России. Традиции, заложенные тогда, не должны быть девальвированы временем. Напротив, они должны найти свое место в современности, давая направление актуальным научным интересам, обеспечивая динамику и преемственность научного процесса.

\section{Литература}

1. Guyard M.-F. La littérature comparée (coll. Que sais-je?). Paris: Presses universitaires de France, 1951. 128 p. 
2. Leerssen J. History and Method of Imagology in Literary Studies // Imagology: a Handbook on the Literary Representation of National Characters. Amsterdam: Rodopi/Brill, 2006. P. 1-6.

3. Пакуляк С.3., Горохов В.Г. История науки с философской точки зрения: кому она нужна? // Высшее образование в России. 2013. № 5. С. 154-156.

4. Ощепков А.Р. Имагология // Знание. Понимание. Умение. 2010. № 1. C. $251-253$.

5. Трыков В.П. Имагология и имагопоэтика // Знание. Понимание. Умение. 2015. № 3. C. 120-129.

6. Якушкина T.B. Сравнительное литературоведение, компаративистика, имагология: точки схождения и расхождения // Взаимодействие языков и культур: исследования выпускников и потенциальных участников программ Фулбрайта: материалы докл. V Междунар. науч. конф. (Череповец, 15 апреля 2016 г.). Череповец: ЧГУ, 2016. С. 157-165.

7. Бочкарева Н.С., Проскурнин Б.М. Образ и миф в английской литературе о России // Вестник Пермского университета. Российская и зарубежная филология. 2015. № 4 (32). С. 142-145.

8. Никола М.И. Имагология как новая область исследований в российском литературоведении // Россия в литературе Запада / отв. ред. В.П. Трыков. М.: МПГУ, 2017. С. 5-15.

9. Полякова О.А. Истоки отечественной имагологии // Научно-методический электронный журнал «Концепт». 2016. № 7. C. 156-163. URL: http://ekoncept.ru/2016/16155.htm.

10. Полякова О.A. Репрезентация образа России во французской литературе в оценках российских компаративистов // Научно-методический электронный журнал «Концепт». 2016. № 9. С. 125-133. URL: http://ekoncept.ru/2016/16195.htm.

11. Папилова E.B. Имагология как гуманитарная дисциплина // Вестник МГГУ им. Шолохова. Филологические науки. 2011. № 4. С. 31-40.

12. Рябчикова E.E. Имагология как раздел литературоведческой компаративистики // Слово.ру: балтийский акцент. 2018. Т. 9. № 2. С. 52-59.

13. Хорев B.A. Имагология и изучение русско-польских литературных связей // Поляки и русские в глазах друг друга. М.: Иидрик, 2000. С. 22-32.

14. Pageaux D.-H. Recherche sur l'imagologie: de l'Histoire culturelle á la Poétique // Revista de Filología Francesa. 1995. № 8. P. 135-160.

15. Янушкевич А.С. От картины мира к образу мира: история становления имаголического текста в русской словесной культуре // Имагология и компаративистика. 2014. № 2. С. 5-16.

16. Киселев В.C. Томск в русской литературе: проблемы и перспективы изучения // Имагология и компаративистика. 2017. № 8. С. 36-61.

17. Сорочан А.Ю. Тверской край в литературе: краеведческий материал и перспективы имагологии // Труды региональных конкурсов научных проектов в 
области фундаментальных и гуманитарных исследований. Тверь: Изд-во Марины Батасовой, 2010. С. 112-120.

18. Орехов В.В. В лабиринте крымского мифа. Симферополь; Нижний Новгород: Растр, 2017. 579 с.

19. Храпунов Н.И. «Восток в Европе»: Крым после присоединения к Российской империи глазами иностранцев // Новое прошлое - The New Past. 2018. № 1. C. $63-78$.

20. Милославская C.K. Учебник русского языка как иностранного - уникальное средство формирования образа России в мире: к теоретическому обоснованию лингвопедагогической имагологии // Вестник РУДН. Вопросы образования: языки и специальность. 2008. № 4. С. 10-15.

21. Кун T. Структура научных революций. М.: Прогресс, 1977. 300 с.

22. Козлова А.А. Имагологический метод в исследованиях литературы и культуры // Обсерватория культуры. 2015. № 3. С. 114-118.

23. Вернадский В.И. Труды по всеобщей истории науки. М: Наука, 1988. 336 с.

24. Киселев В.С. Книжные и журнальные источники «Собрания стихотворений, относящихся к незабвенному 1812 году» // Собрание стихотворений, относящихся к незабвенному 1812 году. Юбилейное издание. М.: Языки славянской культуры, 2015. С. 470-493.

25. Киселев В.С. Идеологический контекст «Собрания стихотворений, относящихся к незабвенному 1812 году» // Собрание стихотворений, относящихся к незабвенному 1812 году. Юбилейное издание. М.: Языки славянской культуры, 2015. C. 449-469.

26. Батюшков К.Н. Сочинения: в 2 т. М.: Художественная литература, 1989. T. $2.719 \mathrm{c}$.

27. К чести России. Из частной переписки 1812 года / сост. М. Бойцов. М.: Современник, 1988. $239 \mathrm{c}$.

28. Михеева Г.В. «Россика» в Российской национальной библиотеке: история, проблемы, перспективы // «Бессмертное отделение “Россика"»: материалы науч. конф. 14 января 2000 г. СПб.: РНБ, 2000. С. 8-18.

29. Пушикин А.С. Полн. собр. соч.: в 19 т. М.: Воскресение, 1994-1997.

30. Catalogue de la section des Russica ou écrits sur la Russie en langues étrangères. St.Pétersbourg, 1873. T. I. 845 p.

31. Романов А.П., Секуторова Г.Д. Проблемы комплектования изданий по россике в РНБ // «Бессмертное отделение "Россика"»: материалы науч. конф. 14 января 2000 г. СПб.: РНБ, 2000. С. 54-61.

32. Кирикова O.A. Аделунг Федор Павлович, фон // Ученые - фондообразователи Санкт-Петербургского филиала Архива Российской академии наук: Краткий биографический справочник. СПб.: Реноме, 2018. С. 12-13.

33. Аделунг Ф.П. Критико-литературное обозрение путешественников по России до 1700 года и их сочинений: в 2 ч. М., 1864. Ч. 1, 2.

34. Нечкина М.В. Василий Осипович Ключевский. История жизни и творчества. М.: Наука, 1974. 635 с. 
35. Козулин В.Н., Курныкин О.Ю., Малышева Н.С., Чернышов Ю.Г. Царь Алексей Михайлович глазами западных современников: образ личности через призму потестарных стереотипов // Былые годы. 2017. Т. 45, № 3. С. 754-764.

36. Корф М.A. Принц датский Иоанн в России. Происшествие 1602 года // Северный архив. 1822. Ч. 2, № 8. С. 82-100.

37. Аделунг Ф.П. Барон Мейерберг и путешествие его по России. С присовокуплением рисунков, представляющих виды, обряды, портреты и т.п., в продолжение сего путешествия собранных. СПб., 1827. 327 с.

38. Орехов B.B. Русская литература и национальный имидж (Имагологический дискурс в русско-французском литературном диалоге первой половины XIX в.). Симферополь: Антиква, 2006. 608 с.

39. Нынешнее состояние России, описанное англичанином, который девять лет прожил при дворе великого царя русского // Русский вестник. 1841. Т. 3, № 7. С. 161-182; № 9. С. 567-596.

40. Блок Г.П. Пушкин в работе над историческими источниками. М.; Л.: Издво АН СССР, 1949. $214 \mathrm{c}$.

41. Устрялов Н.Г. Сказания современников о Дмитрии Самозванце. СПб., 1831-1834. Ч. $1-5$.

42. Макушев В.В. Сказания иностранцев о быте и нравах славян. СПб.: Тип. Э. Веймара, $1861.178 \mathrm{c}$.

43. Ключевский В.О. Сказания иностранцев о Московском государстве. М.: Прометей, 1991. 334 с.

44. Рущинский Л.П. Религиозный быт русских по сведениям иностранных писателей XVI и XVII в. М.: Университетская типография, 1871. 335 с.

45. Коялович М.О. История русского самосознания по историческим памятникам и научным сочинениям. Минск: Лучи Софии, 1997. 688 с.

46. Лотман Ю.М. К вопросу об источниковедческом значении высказываний иностранцев о России // Сравнительное изучение литератур: сб. ст. к 80летию акад. М.П. Алексеева. Л.: Наука, 1976. С. 125-132.

47. Кузнецова Н.И. Наука в ее истории (Методологические проблемы). М.: Наука, 1982. $126 \mathrm{c}$.

48. Голубева О.Д. М.А. Корф. СПб.: Изд-во РНБ, 1995. 167 с.

49. Поршнева О.С. Историческая имагология в современной российской историографии // Урал индустриальный. Бакунинские чтения: Индустриальная модернизация Урала в XVIII-XXI вв.: XII Всероссийская науч. конф., посв. 90летию проф. А.В. Бакунина. Екатеринбург: УФУ, 2014. С. 126-129.

50. Бойщов М.А. Что такое потестарная имагология? // Власть и образ: очерки потестарной имагологии. СПб.: Алетейя, 2010. С. 5-37.

51. Земсков В.Б. Образ России «на переломе» времен. (Теоретический аспект: рецепция и репрезентация «другой» культуры) // Новые российские гуманитарные исследования. 2006. № 1. URL: http://www.nrgumis.ru/articles/81/.

52. Генинг В.Ф., Левченко В.Н. Археология древностей - период зарождения науки (конец XVIII - 70-е годы XIX в.). Киев: АН Украины, 1992. 67 с. 
53. Кулаковский Ю.А. Прошлое Тавриды. Краткий исторический очерк. Киев, 1906. $144 \mathrm{c}$.

54. Формозов А.А. Очерки по истории русской археологии. М.: Изд-во АН CCCP, 1961. $128 \mathrm{c}$.

55. Тункина И.В. Русская наука о классических древностях юга России (XVIII - середина XIX в.). СПб.: Наука, 2002. 676 с.

56. Амирова Т.А., Ольховников Б.А., Рождественский Ю.В. Очерки по истории лингвистики. М.: Наука, 1975. 599 с.

57. Cadot M. La Russie dans la vie intellectuelle française (1839-1856). P.: Fayard, 1967. $641 \mathrm{p}$.

58. Corbet C. L'opinion française face à l'inconnue russe (1799-1894). P.: Didier, 1967. $488 \mathrm{p}$.

59. Трыков В.П., Ощчепков А.Р. Французская «россика»: особенности понимания России // Тезаурусный анализ мировой культуры: сб. науч. тр. М.: Изд-во Моск. гуманит. ун-та, 2013. Вып. 25. С. 57-70.

60. Михальская Н.П. Образ России в английской художественной литературе IX-XIX вв. М.: МПГУ, 1995. 150 с.

61. Иванова Л.П. Имагология как новое направление лингвистики // Мова i культура. Киев: Д. Бураго, 2012. Вип. 15, т. 6. С. 73-76.

62. Наливайко Д.С. Казацька християнська республика (Запорозька Січ у західноєвропейських літературних пам’ятках). Київ: Дніпро, 1992. 494 с.

63. Наливайко Д.С. Очима Заходу. Рецепція України в Західній Свропі XIXVIII ст. Київ: Основи, 1998. 578 с.

64. Чжан M. «Письма знатного иностранца» К.М. Станюковича: синтез и модернизация традиций // Ученые записки Крымского федерального университета. Филологические науки. 2017. Т. 4 (70), № 1. С. 119-138.

65. Поляков О.Ю. Становление и развитие категориального аппарата имагологии // Вестник Вятского государственного гуманитарного университета. 2014. № 9. C. $125-135$.

66. Leerssen J. Imagologia: O zastosowaniu etniczności do nadawania światu sensu // Porównania. 2017. Vol. 21. P. 9-29.

\section{Background of Russian Imagology: Tradition as an Indication of Target}

Imagologiya $i$ komparativistika - Imagology and Comparative Studies, 2020, 14, pp. 143-167. DOI: 10.17223/24099554/14/7

Vladimir V. Orekhov, V.I. Vernadsky Crimean Federal University (Simferopol, Russian Federation). E-mail: v-orehov@mail.ru

Keywords: imagology, reverse reception, meta-image, imagological communication, Rossica.

Focusing on the history of Russian imagology, the article aims at identifying the origins of the imagological interests in research and public thought in Russia in the first and second thirds of the 20th century as well as research approaches of that time 
that may be required by modern imagology. This analytical insight arises from the endeavor of contemporary scholars to update and develop the imagology paradigm. The Patriotic War of 1812 and the entry of Russian troops into Paris in 1814 gave a powerful impulse to the imagological interests in Russian society. These events highlighted the irrational nature of European stereotypes and provided an opportunity for the Russian intellectual elite to observe how the European image of Russia evolves depending on the historical situation, which, in its turn, induced the Russians to collect and conceptualise the information about the image of Russia in European texts of different epochs. The Rossica Department in the Imperial Public Library was opened for the scholars to do bibliographic research of foreign publications about Russia. Commenting foreign essays about Russia was an important part of Russian academic and journalistic activity. Such publications regularly appeared in Syn Otechestva, Otechestvennye zapiski, Severnyy Arkhiv, Sovremennik, Biblioteka dlya chteniya, Russkiy vestnik, and Zhurnal Ministerstva narodnogo prosveshcheniya. The first imagological research proper was V.A. Klyuchevsky's Skazaniya inostrantsev o Moskovskom gosudarstve [Legends of Foreigners about the Moscow State, 1866]. Without a critical analysis of foreign sources, the historian uses excerpts from different foreign texts to reconstruct an integral image of the Moscow state in the European consciousness. Although the first Russian imagological researches appeared in history, they laid the basis for the development of literary criticism. The book collection "Rossica" allowed Russian and foreign scholars (M.P. Alekseev, B.L. Modzalevsky, E.V. Tarle, M. Kadot) to study the Western literary opinion about Russia. Yu.M. Lotman relied on the imagological observations made by V.A. Klyuchevsky and his followers. Methodology of Soviet imagological research in literary criticism (M.P. Alekseev, B.G. Reizov, A.K. Vinogradov) was guided by the principles of history. These facts give grounds to speak about the formation of the Russian tradition of imagological researches, which has two characteristics: 1) following the principle of historicity and 2) focus on the functioning of the image of Russia in European literature of different epochs. In this context, it seems relevant for the Russian imagological works to focus on the phenomenon of "reverse reception" in Russian literature of the 19th century, that is on the Russian writers' endeavor to comprehend the European image of Russia (to create a "meta-image") and to oppose this image with their own holistic idea of Russia and its national features.

\section{References}

1. Guyard, M.-F. (1951) La littérature comparée (coll. Que sais-je?). Paris: Presses universitaires de France.

2. Leerssen, J. (2006) History and Method of Imagology in Literary Studies. In: Leerssen, J. (ed.) Imagology: A Handbook on the Literary Representation of National Characters. Amsterdam: Rodopi/Brill. pp. 1-6.

2. Pakulyak, S.Z. \& Gorokhov, V.G. (2013) The history of science from the philosophical point of view. Vysshee obrazovanie v Rossii - Higher Education in Russia. 5. pp. 154-156. (In Russian). 
3. Oshchepkov, A.R. (2010) Imagology. Znanie. Ponimanie. Umenie Knowledge. Understanding. Skill. 1. pp. 251-253. (In Russian).

4. Trykov, V.P. (2015) Imagology and imagopoetics. Znanie. Ponimanie. Umenie-Knowledge. Understanding. Skill. 3. pp. 120-129. (In Russian). DOI: 10.17805/zpu.2015.3.10

5. Yakushkina, T.V. (2016) [Comparative literary studies, comparative studies, imagology: points of convergence and divergence]. Vzaimodeystvie yazykov i kul'tur: issledovaniya vypusknikov i potentsial'nykh uchastnikov programm Fulbrayta [Interaction of languages and cultures: research of alumni and potential participants in Fulbright programs]. Proc. of the Fifth International Conference. Cherepovets, April 15, 2016. Cherepovets: Cherepovets State University. pp. 157-165. (In Russian).

6. Bochkareva, N.S. \& Proskurnin, B.M. (2015) Obraz i mif v angliyskoy literature o Rossii [Image and myth in English literature about Russia]. Vestnik Permskogo universiteta. Rossiyskaya i zarubezhnaya filologiya - Perm University Herald. Russian and Foreign Philology. 4(32). pp. 142-145.

7. Nikola, M.I. (2017) Imagologiya kak novaya oblast' issledovaniy v rossiyskom literaturovedenii [Imagology as a new area of research in Russian literary criticism]. In: Trykov, V.P. (ed.) Rossiya v literature Zapada [Russia in the literature of the West]. Moscow: Moscow State Pedagogical University. pp. 5-15.

8. Polyakova, O.A. (2016) Beginnings of Russian imagology. Kontsept. 7. pp. 156163. (In Russian). [Online] Available from: http://e-koncept.ru/2016/16155.htm

9. Polyakova, O.A. (2016) Representation of the Image of Russia in French Literature in the Works of Russian Comparativists. Kontsept. 9. pp. 125-133. (In Russian). [Online] Available from: http://e-koncept.ru/2016/16195.htm

10. Papilova, E.V. (2011) Imagologiya kak gumanitarnaya distsiplina [Imagology as a humanitarian discipline]. Vestnik MGGU im. Sholokhova. Filologicheskie nauki. 4. pp. $31-40$.

11. Ryabchikova, E.E. (2018) Imagology as a Part of Compartive Literary Studies. Slovo.ru: baltiyskiy aktsent - Slovo.ru: Baltic Accent. 9(2). pp. 52-59. (In Russian). DOI: 10.5922/2225-5346-2018-2-4

12. Khorev, V.A. (2000) Imagologiya i izuchenie russko-pol'skikh literaturnykh svyazey [Imagology and the study of Russian-Polish literary ties]. In: Khorev, V.A. (ed.) Polyaki i russkie v glazakh drug druga [Poles and Russians in the eyes of each other]. Moscow: Indrik. pp. 22-32.

13. Pageaux, D.-H. (1995) Recherche sur l'imagologie: de l'Histoire culturelle á la Poétique. Revista de Filología Francesa. 8. pp. 135-160.

14. Yanushkevich, A.S. (2014) From the world picture to the world image: the history of the imagological text formation in Russian literary culture. Imagologiya $i$ komparativistika - Imagology and Comparative Studies. 2. pp. 5-16. (In Russian). DOI: $10.17223 / 24099554 / 2 / 1$

15. Kiselev, V.S. (2017) Tomsk in Russian literature: problems and prospects of research. Imagologiya i komparativistika - Imagology and Comparative Studies. 8. pp. 36-61. (In Russian). DOI: 10.17223/24099554/8/3 
16. Sorochan, A.Yu. (2010) Tverskoy kray v literature: kraevedcheskiy material i perspektivy imagologii [Tver Region in Literature: Local History Material and Prospects of Imagology]. In: Trudy regional'nykh konkursov nauchnykh proektov v oblasti fundamental'nykh $i$ gumanitarnykh issledovaniy [Proceedings of Regional Competitions of Scientific Projects in the Field of Fundamental and Humanitarian Research]. Tver: Izd-vo Mariny Batasovoy. pp. 112-120.

17. Orekhov, V.V. (2017) V labirinte krymskogo mifa [In the labyrinth of the Crimean myth]. Simferopol; Nizhniy Novgorod: Rastr.

18. Khrapunov, N.I. (2018) "The Orient in Europe": the Crimea after Accession to Russian Empire as Viewed by Foreigners. Novoe proshloe - The New Past. 1. pp. 6378. (In Russian).

19. Miloslavskaya, S.K. (2008) Uchebnik russkogo yazyka kak inostrannogo uni-kal'noe sredstvo formirovaniya obraza Rossii v mire: $\mathrm{k}$ teoreticheskomu obosnovaniyu lingvopedagogicheskoy imagologii [The textbook of Russian as a foreign language is a unique means of forming the image of Russia in the world: to the theoretical substantiation of linguo-pedagogical imagology]. Vestnik RUDN. Voprosy obrazovaniya: yazyki i spetsial'nost'. 4. pp. 10-15.

20. Kuhn, T. (1977) Struktura nauchnykh revolyutsiy [The Structure of Scientific Revolutions]. Translated from English. Moscow: Progress.

21. Kozlova, A.A. (2015) Imagological Method in Literary and Cultural Research. Observatoriya kul'tury - Observatory of Culture. 3. pp. 114-118. (In Russian).

22. Vernadsky, V.I. (1988) Trudy po vseobshchey istorii nauki [Transactions on the general history of science]. Moscow: Nauka.

23. Kiselev, V.S. (2015a) Knizhnye i zhurnal'nye istochniki "Sobraniya stikhotvoreniy, otnosyashchikhsya k nezabvennomu 1812 godu" [Book and magazine sources "Collection of poems relating to the unforgettable 1812"]. In: Aizikova, I.A. (ed.) Sobranie stikhotvoreniy, otnosyashchikhsya k nezabvennomu 1812 godu [Collection of Poems Relating to the Unforgettable 1812]. Moscow: Yazyki slavyanskoy kul'tury. pp. 470-493.

24. Kiselev, V.S. (2015b) Ideologicheskiy kontekst "Sobraniya stikhotvoreniy, otno-syashchikhsya k nezabvennomu 1812 godu" [The ideological context of the "Collection of poems relating to the unforgettable 1812"]. In: Aizikova, I.A. (ed.) Sobranie stikhotvoreniy, otnosyashchikhsya k nezabvennomu 1812 godu [Collection of Poems Relating to the Unforgettable 1812]. Moscow: Yazyki slavyanskoy kul'tury. pp. 449-469.

25. Batyushkov, K.N. (1989) Sochineniya: $V 2 t$. [Works: in 2 vols]. Vol. 2. Moscow: Khudozhestvennaya literatura.

26. Boytsov, M. (ed.) (1988) K chesti Rossii. Iz chastnoy perepiski 1812 goda [To the Honor of Russia. From Private Correspondence of 1812]. Moscow: Sovremennik.

27. Mikheeva, G.V. (2000) ["Rossica" in the Russian National Library: history, problems, prospects]. "Bessmertnoe otdelenie 'Rossika'" [The Immortal Rossica Department]. Proc. of the Conference. January 14, 2000. St. Petersburg: RNL. pp. 8-18. (In Russian). 
28. Pushkin, A.S. (1994-1997) Polnoe sobranie sochineniy: V 19 t. [Complete Works: in 19 vols]. Moscow: Voskresenie.

29. The State Public Library. (1873) Catalogue de la section des Russica ou écrits sur la Russie en langues étrangères. St. Petersburg: Imperial Academy of Sciences.

30. Romanov, A.P. \& Sekutorova, G.D. (2000) [Problems of acquisition of Russian publications in the National Library of Russia]. "Bessmertnoe otdelenie 'Rossi$k a$,' [The Immortal Rossica Department]. Proc. of the Conference. January 14, 2000. St. Petersburg: RNL. pp. 54-61. (In Russian).

31. Kirikova, O.A. (2018) Adelung Fedor Pavlovich, fon [Fedor Pavlovich von Adelung]. In: Basargina, E.Yu. \& Tunkina, I.V. (eds) Uchenye - fondoobrazo-vateli Sankt-Peterburgskogo filiala Arkhiva Rossiyskoy akademii nauk: Kratkiy biograficheskiy spravochnik [Scientists - fund-builders of the St. Petersburg Branch of the Archive of the Russian Academy of Sciences: A Brief Biographical Reference]. St. Petersburg: Renome. pp. 12-13.

32. Adelung, F.P. (1864) Kritiko-literaturnoe obozrenie puteshestvennikov po Rossii do 1700 goda i ikh sochineniy [Critical and literary review of travelers in Russia before 1700 and their works]. Moscow: [s.n.].

33. Nechkina, M.V. (1974) Vasiliy Osipovich Klyuchevskiy. Istoriya zhizni $i$ tvorche-stva [Vasily Osipovich Klyuchevsky. The history of life and work]. Moscow: Nauka.

34. Kozulin, V.N., Kurnykin, O.Yu., Malysheva, N.S. \& Chernyshov, Yu.G. (2017) Tsar Alexis Mikhailovich through the Eyes of Western Contemporaries: a Personal Image in the Light of Potestar Stereotypes. Bylye gody. 45(3). pp. 754-764. (In Russian). DOI: 10.13187/bg.2017.3.754

35. Korf, M.A. (1822) Prints datskiy Ioann v Rossii. Proisshestvie 1602 goda [Prince John of Denmark in Russia. The incident of 1602]. Severnyy arkhiv. 2(8). pp. $82-100$.

36. Adelung, F.P. (1827) Baron Meyerberg i puteshestvie ego po Rossii. S prisovo-kupleniem risunkov, predstavlyayushchikh vidy, obryady, portrety $i$ t.p., $v$ prodolzhenie sego puteshestviya sobrannykh [Baron Meyerberg and his travels across Russia. With drawings representing species, rituals, portraits, etc., collected during the journey]. St. Petersburg: [s.n.].

37. Orekhov, V.V. (2006) Russkaya literatura i natsional'nyy imidzh (Imagologicheskiy diskurs $v$ russko-frantsuzskom literaturnom dialoge pervoy poloviny XIX v.) [Russian literature and national image (Imagological discourse in the Russian-French literary dialogue of the first half of the 19th century)]. Simferopol: Antikva.

38. Anon. (1841) Nyneshnee sostoyanie Rossii, opisannoe anglichaninom, kotoryy devyat' let prozhil pri dvore velikogo tsarya russkogo [The current state of Russia, described by an Englishman who lived for nine years at the court of the great Russian Tsar]. Russkiy vestnik. 3(7). pp. 161-182.

39. Blok, G.P. (1949) Pushkin v rabote nad istoricheskimi istochnikami [Pushkin in the work on historical sources]. Moscow; Leningrad: USSR AS. 
40. Ustryalov, N.G. (1831-1834) Skazaniya sovremennikov o Dmitrii Samozvantse [Legends of contemporaries about Dmitry the Pretender]. St. Petersburg: Imperial Academy of Sciences.

41. Makushev, V.V. (1861) Skazaniya inostrantsev o byte i nravakh slavyan [Legends of foreigners about the life and customs of the Slavs]. St. Petersburg: Tip. E. Veymara.

42. Klyuchevsky, V.O. (1991) Skazaniya inostrantsev o Moskovskom gosudarstve [Legends of foreigners about the Moscow state]. Moscow: Prometey.

43. Rushchinsky, L.P. (1871) Religioznyy byt russkikh po svedeniyam inostran$n y k h$ pisateley XVI $i$ XVII $v$. [Religious life of Russians according to foreign writers of the 16th and 17th centuries]. Moscow: Universitetskaya tip-ya.

44. Koyalovich, M.O. (1997) Istoriya russkogo samosoznaniya po istoricheskim pamyatnikam i nauchnym sochineniyam [The history of Russian identity based on historical monuments and scientific writings]. Minsk: Luchi Sofii.

45. Lotman, Yu.M. (1976) K voprosu ob istochnikovedcheskom znachenii vyskazyvaniy inostrantsev o Rossii [On the source study of statements by foreigners about Russia]. In: Bushmin, A.S. (ed.) Sravnitel'noe izuchenie literature [Comparative Literature Studies]. Leningrad: Nauka. pp. 125-132.

46. Kuznetsova, N.I. (1982) Nauka v ee istorii (Metodologicheskie problemy) [Science in its history (Methodological problems)]. Moscow: Nauka.

47. Golubeva, O.D. (1995) M.A. Korf. St. Petersburg: RNL.

48. Porshneva, O.S. (2014) Istoricheskaya imagologiya v sovremennoy rossiyskoy istoriografii [Historical imagology in contemporary Russian history]. Ural industrial'nyy. Bakuninskie chteniya: Industrial 'naya modernizatsiya Urala v XVIII-XXI vv. [The Industrial Ural. The Bakunin Readings: Industrial Modernization of the Urals in the 18th -21 st centuries]. Proc. of the 12th All-Russian Conference. Yekaterinburg: Ural Federal University. pp. 126-129.

49. Boytsov, M.A. (2010) Chto takoe potestarnaya imagologiya? [What is potestary imagology?]. In: Boytsov, M.A. \& Uspensky, F.B. (eds) Vlast' $i$ obraz: ocherki potestarnoy imagologii [Power and Image: Essays on Potestary Imagology]. St. Petersburg: Aleteyya. pp. 5-37.

50. Zemskov, V.B. (2006) Obraz Rossii "na perelome" vremen. (Teoreticheskiy aspekt: retseptsiya i reprezentatsiya "drugoy" kul'tury) [The image of Russia "at the turning point" of times. (Theoretical aspect: reception and representation of "another" culture]. Novye rossiyskie gumanitarnye issledovaniya. 1. [Online] Available from: http://www.nrgumis.ru/articles/81/

51. Gening, V.F. \& Levchenko, V.N. (1992) Arkheologiya drevnostey - period zarozhdeniya nauki (konets XVIII - 70-e gody XIX v.) [Archeology of antiquities - the period of the birth of science (the late 18th - 1870s)]. Kiev: Ukrainian AS.

52. Kulakovsky, Yu.A. (1906) Proshloe Tavridy. Kratkiy istoricheskiy ocherk [The past of Taurida. A brief historical sketch]. Kiev: [s.n.].

53. Formozov, A.A. (1961) Ocherki po istorii russkoy arkheologii [Essays on the history of Russian archeology]. Moscow: USSR AS. 
54. Tunkina, I.V. (2002) Russkaya nauka o klassicheskikh drevnostyakh yuga Rossii (XVIII - seredina XIX v.) [Russian science about the classical antiquities of the south of Russia (the 18th - mid 19th century)]. St. Petersburg: Nauka.

55. Amirova, T.A., Olkhovnikov, B.A. \& Rozhdestvensky, Yu.V. (1975) Ocherki po istorii lingvistiki [Essays on the history of linguistics]. Moscow: Nauka.

56. Cadot, M. (1967) La Russie dans la vie intellectuelle française (1839-1856). Paris: Fayard.

57. Corbet, C. (1967) L'opinion française face à l'inconnue russe (1799-1894). Paris: Didier.

58. Trykov, V.P. \& Oshchepkov, A.R. (2013) Frantsuzskaya "rossika": osobennosti ponimaniya Rossii [French "Rossica": Peculiarities of Understanding Russia]. In: Lukov, Vl.A. (ed.) Tezaurusnyy analiz mirovoy kul'tury [Thesaurus Analysis of World Culture]. Vol. 25. Moscow: Moscow University for the Humanities. pp. 57-70.

59. Mikhalskaya, N.P. (1995) Obraz Rossii v angliyskoy khudozhestvennoy literature $I X-X I X v v$. [The image of Russia in English fiction of the 9th - 19th centuries]. Moscow: Moscow State Pedagogical University.

60. Ivanova, L.P. (2012) Imagologiya kak novoe napravlenie lingvistiki [Imagology as a new direction of linguistics]. Mova i kul'tura. 15(6). pp. 73-76.

61. Nalivayko, D.S. (1992) Kazats'ka khristiyans'ka respublika (Zaporoz'ka Sich u zakhidnoevropeys'kikh literaturnikh pam'yatkakh) [Cossack Christian Republic (Zaporozka Sich at Western European literary memorials)]. Kyiv: Dnipro.

62. Nalivayko, D.S. (1998) Ochima Zakhodu. Retseptsiya Ukraïni v Zakhidniy Cvropi XI-XVIII st. [Through the eyes of the West. Reception of Ukraine in Western Europe in the 11th -18 th centuries]. Kyiv: Osnovi.

63. Zhang, M. (2018) Cycle-forming connections in the first collection of stories by K.M. Stanyukovich. Uchenye zapiski Krymskogo federal'nogo universiteta. Filologicheskie nauki. 4(1). pp. 119-138. (In Russian).

64. Polyakov, O.Yu. (2014) Stanovlenie i razvitie kategorial'nogo apparata imagologii [Formation and development of imagology categorical apparatus]. Vestnik Vyatskogo gosudarstvennogo gumanitarnogo universiteta. 9. pp. 125-135.

65. Leerssen, J. (2017) Imagologia: O zastosowaniu etniczności do nadawania światu sensu. Porównania. 21. pp. 9-29. 